DOI https://doi.org/10.18551/rjoas.2017-12.20

\title{
THE ABILITY OF INDONESIA COCOA BEANS IN FULFILLING THE DOMESTIC NECESSITY OF INTERMEDIATE PROCESSED COCOA INDUSTRY
}

\author{
Rahmawiliyanti* \\ Postgraduate Program in Agriculture Science, Agricultural Faculty, University of Brawijaya \& \\ Department of Agribusiness, Agricultural Faculty, Wijaya Kusuma Surabaya University, \\ Indonesia
}

\author{
Hanani Nuhfil, Anindita Ratya, Syafrial \\ Department of Agribusiness, Agricultural Faculty, University of Brawijaya, Indonesia
}

*E-mail: leni.ilma@yahoo.com

\begin{abstract}
Intermediate processed cocoa and chocolate industries in the world show increasing because the chocolate products consumption is growing at a very strong pace. Indonesia is a country with the potential to become the largest exporter of intermediate processed cocoa. The objectives of this research are: to analyze the ability of production of domestic cocoa beans to meet the demand for intermediate processed cocoa industry; to analyze the factors that influence the demand for cocoa beans to produce cocoa paste, cocoa butter and cocoa powder. This research uses simultaneous equation model with 2SLS method. This study states that the cocoa beans necessity required by industry of cocoa paste, cocoa butter and cocoa powder can be fulfilled by domestic production of cocoa beans. Cocoa beans demand for cocoa paste industry is influenced by wages, cocoa beans demand for cocoa butter and cocoa powder industries. Cocoa beans demand to produce cocoa butter is affected by world cocoa price, interest rate, cocoa beans demand for cocoa paste and cocoa powder industries.
\end{abstract}

\section{KEY WORDS}

Production, demand, cocoa beans, cocoa butter, cocoa paste, cocoa powder.

There are 127 exporting countries and 167 importing countries listed as cocoa beans trading countries in the world market. Mostly, cocoa beans need in the world are filled by cocoa beans producing countries from African (Ivory Coast, Ghana, Nigeria and Cameroon), Asia (Indonesia, Malaysia and Papua New) and America (Brazil, Ecuador and Colombia). Ivory Coast and Ghana are the largest producer and exporter countries in the world. In 2010, the Ivory Coast and Ghana market share were $30 \%$ and $10.2 \%$ respectively and increased respectively to $38.4 \%, 18.5 \%$ in 2016 .

Indonesia in 2010 was still the third-largest producer and exporter of cocoa beans in the world after Ivory Coast and Ghana. Market share Indonesia in the cocoa beans world market in 2010 was $14.3 \%$ and continued to decline in the following years. The declining market share of Indonesia cocoa beans in the world market is due to the policy of limiting the export of cocoa beans in order to fulfill the need of domestic processed cacao industry. According to Suranovic M (2003), an export tax is a tax which is obtained from exported goods and it can be set on a specific or an ad valorem tariff. Indonesia government attempted to make Indonesia as the greatest country exporter of cocoa intermediate in the world according to Indonesia Presidential Regulation number 28 Year 2008 stating that cocoa and cocoa processing industry is a national priority industry, world-class industry and mainstay industry of the future. This is very possible to achieve considering Indonesia is a cocoa beans producing country. Cocoa beans is the raw material of intermediate processed cocoa that support the chocolate processing industry

Natural resources owned by Indonesia and the high consumption of world chocolate, make many global companies invest in Indonesia. In 2014, there were 16 processed cocoa 
and chocolate companies with 400,000 tons of production capacity and increasing to 19 companies with a capacity of 700,000 tons in 2016. New investors in processed cocoa and chocolate industries are multinational companies. They are Guanchong Cocoa and JB Cocoa from Malaysia with 180,000 tons production capacity, Barry Comextra from Switzerland with 60,000 tons, Cargill Cocoa Holand with 65,000 tons and ADM Cocoa from the United States. The high production capacity causes increased demand for cocoa beans as raw materials. (BTCOCOA, 2014).

A study examining the demand for cocoa beans for intermediate processed cocoa industry has not been found yet, however, two previous studies are found related to the demand for a commodity as a raw material of a processed industry. Desweni et al (2015) revealed that demand for corn input by poultry industry in Indonesia is significantly and positively influenced by poultry prices and the amount of labor in the livestock industry, while poultry prices have an effect on industry demand with negative relationship direction. Ferrianta Y (2012) in its research using 2 SLS method stated that corn demand by animal feed industry is significantly influenced by feed price $(\alpha=3,9 \%)$ and corn demand for food industry last year with $\alpha=0,02 \%$. The price of maize has a significant effect on the level of $\alpha$ $=26 \%$. Soybean price has no significant effect on feed industry demand and has negative relationship direction. It can be concluded both from the Ferryanta (2012) and Desweni et al (2015) studies that the price of output from an industry influences its input demand.

In order to support the Indonesia Presidential Regulation number 28 Year 2008 which makes chocolate and cocoa processing industries as a national priority industry, therefore it needs a deep study of the need and availability of cocoa beans as raw materials for intermediate processed cocoa, as well as the factors that affect the demand for cocoa beans for each intermediate processed cocoa industry. The interesting thing to answer is whether as a cocoa beans producer country, Indonesia is automatically able to fulfill the demand for domestic cocoa beans. The increasing of downstream industry, especially intermediate processed cocoa industry, is expected to increase the production and export of intermediate processed cocoa to compete in the international market. Therefore, based on the problems, the purpose of this study is to analyze the ability of domestic cocoa beans production in fulfilling the demand for intermediate processed cocoa industry and analyze the factors that influence the demand for cocoa beans to produce cocoa paste, cocoa butter and cocoa powder. The lack of research on the demand for cocoa beans for intermediate processed cocoa industry and the factors that influence it, is the renewal in this study.

\section{METHODS OF RESEARCH}

This study used secondary data from 1992 to 2015 in relation to factors affecting the production of cocoa beans and cocoa beans demand from the intermediate processed cocoa industry. Data sources come from Trademap, ICCO, FAO, UN Comtrade, World, Indonesia Central Bureau of Statistics, Directorate General of Plantation, Labor Department, Coffee and Cocoa Research Center (Puslitkoka, Jember).

Graphical and trend analysis are used to determine the ability of domestic cocoa beans to fulfill the cocoa beans demand for domestic processed cocoa industry. By graphical, it can be seen and compared, the movement of production volumes and cocoa beans demand for the intermediate processed cocoa industry. Trend analysis is used to predict the production volume of cocoa beans and cocoa beans demand in the next years.

Cocoa beans demand for the intermediate processed cocoa industry is used as raw material for cocoa paste, cocoa butter and cocoa powder. The total of Indonesia cocoa beans demand is the sum of cocoa beans demand for processed cocoa industry to produce cocoa paste, cocoa butter and cocoa powder.

$$
D_{b k} k_{\text {lna }}=D_{b k}^{c b}+D_{b k}^{c p}+D_{b k}^{c p d}
$$

Where:

$\mathrm{Dbk}_{\text {Ina }}=$ total of Indonesia cocoa beans demand; 
$D_{b k}{ }^{c b}=$ demand for cocoa beans to produce cocoa paste;

$D_{b k}{ }^{c p}=$ demand for cocoa beans to produce cocoa butter;

$\mathrm{D}_{\mathrm{bk}}{ }^{\mathrm{cpd}}=$ demand for cocoa beans to produce cocoa powder.

Cocoa beans are used by processed cocoa beans industry as the main inputs for intermediate processed cacao processing, therefore cocoa beans demand function in the processed cacao industry is the function of derived demand from the industry production function of cocoa paste, cocoa butter, cocoa powder.

The following are sequentially arranged equations: (1) Function of cocoa butter demand which is derivative function of cocoa butter production function, (2) Function of cocoa paste demand which is derivative function of cocoa paste production function. (3) Function of cocoa powder demand which is derivative function of cocoa powder production function.

$$
\begin{aligned}
& D_{b k}^{c b}=a_{0}+a_{1} P c b_{l n a}+a_{2} P b k_{l n a}+a_{3} i+a_{4} W+a_{5} D_{b k}^{c p}+a_{6} D_{b k}{ }^{c p d}+a_{7} D_{b k}^{c b} L+U_{1} \\
& D_{b k}^{c p}=b_{0}+b_{1} P c p_{l n a}+b_{2} P b k_{l n a}+b_{3} i+b_{4} W+b_{5} D_{b k}^{c b}+b_{6} D_{b k}^{c p d}+b_{7} D_{b k}^{c p} L+U_{2} \\
& D_{b k}{ }^{c p d}=c_{0}+c_{1} P c p d_{l n a}+c_{2} P b k_{l n a}+c_{3} i+c_{4} W+c_{5} D_{b k}^{c b}+c_{6} D_{b k}^{c p}+c_{7} D_{b k}^{c p d} L+U_{3}
\end{aligned}
$$

Where:

$\mathrm{Pbk}_{\text {Ina }}=$ Price of Indonesia cocoa beans;

$\mathrm{Pcb}_{\text {Ina }}=$ Price of Indonesia cocoa butter;

$\mathrm{Pcp}_{\text {Ina }}=$ Price of Indonesia cocoa paste;

$\mathrm{Pcpd}_{\text {Ina }}=$ Price of Indonesia cocoa powder;

$\mathrm{i}=$ Interest rate;

$\mathrm{W}=$ Wages;

$D_{b k}{ }^{c b} L=$ Lag of demand for cocoa beans to produce cocoa paste;

$D_{b k}{ }^{c p} \mathrm{~L}=$ Lag of demand for cocoa beans to produce cocoa butter;

$D_{b k}{ }^{c p d} \mathrm{~L}=$ Lag of demand for cocoa beans to produce cocoa powder.

\section{RESULTS AND DISCUSSION}

Since the adoption of export restrictions on cocoa beans in 2010, the concentration of cocoa beans has been directed to fulfill the cocoa beans demand for domestic processed cocoa industry.

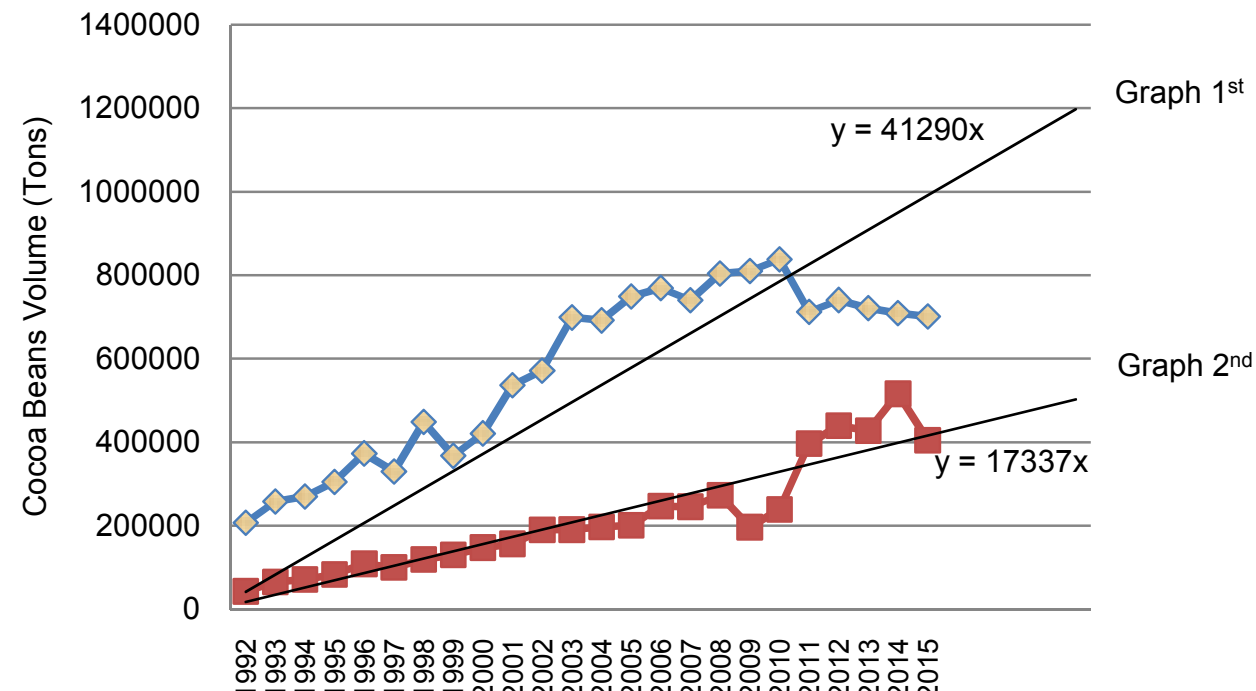

Source : Directorate General of Plantatios (2014) dan FAO

Figure 1 - Production and Demand for Indonesia Cocoa Beans 
The aim of export limiting of cocoa beans is to enable the Indonesia nation to enjoy the added value of cocoa beans that have been enjoyed by the importing countries of Indonesia cocoa beans. Based on data obtained from directorate general of plantations and FAO, the quantity of cocoa beans production volume shows that there is a tendency to increase. There is a decrease in cocoa beans production after 2010 because of the number of old cocoa trees and climate change (EI Nino and a lot of rainfall). Nevertheless, the decrease of cocoa beans production can still fulfill the necessity of the intermediate processed cocoa industry.

Figure 1 consists of 2 charts. Graph $1^{\text {st }}$ (blue) describes the production volume of cocoa beans. Graph $2^{\text {nd }}$ (red) describes the demand volume of cocoa beans to fulfill the necessity of the intermediate processed cocoa industry. It can be seen that graph $1^{\text {st }}$ is higher than graph $2^{\text {nd }}$. It means that the production of Indonesia cocoa beans is able to fulfill the necessity of domestic intermediate processed cocoa industry. There has been an increase in the demand for cocoa beans by the intermediate processed cocoa industry after the imposition of export restrictions on domestic cocoa beans. This shows that the regulation of the Minister of Finance No. 67 / PMK.011 / 2010 plays an effective role in efforts to increase the production of intermediate processed cocoa industry products. It appears also in figure 1 and table 1 that both production and demand for cocoa beans have a rising trend in the future.

Table 1 - Production and Demand Trend of Cocoa Beans

\begin{tabular}{|c|c|c|}
\hline Year & Cocoa Bean Production & Demand for Cocoa Bean \\
\hline 2017 & 706407 & 451484 \\
\hline 2018 & 732630 & 468896 \\
\hline 2019 & 758853 & 486308 \\
\hline 2020 & 785076 & 503720 \\
\hline 2021 & 811299 & 521132 \\
\hline
\end{tabular}

Source: FAO and Trademap.

Statistical test results shows that the exogenous variables used in the model have the opportunity to explain $96.72 \%\left(R^{2}\right)$ of the endogenous variable variation (demand for cocoa beans to produce cocoa butter) and the remaining $3,28 \%$ is influenced by other variables that are not found in the model.

Cocoa beans demand for cocoa butter industry is cocoa beans demand to produce cocoa butter. It simultaneously and partially is affected by the world cocoa beans price, interest rate, cocoa beans demand to produce cocoa paste and cocoa beans demand to produce cocoa powder. This is indicated by the F-value of 132.60 with significance level smaller than $0.01 \%$ and $t$-value with significance level smaller than $0.07 \%$.

The world cocoa beans price affects the demand for cocoa beans to produce cocoa butter with negative relations. It means that the higher the world cocoa beans price will decrease the demand for cocoa beans to produce cocoa butter, because the price of Indonesia cocoa beans is also affected by the world price of cocoa beans. Interest rate shows a negative relationship with demand for cocoa beans to produce cocoa butter. It shows that the higher the interest rate, the demand for cocoa beans to produce cocoa butter is lower. The increased interest rate will cause the interest expense of capital loans to be increasing.

Cocoa beans demand to produce cocoa paste and cocoa powder have a positive relationship to cocoa beans demand to produce cocoa butter. The higher the demand for cocoa beans to produce cocoa paste and cocoa powder, the greater the demand for cocoa beans to produce butter. It shows that there is a complementary characteristic between cocoa paste to cocoa butter and cocoa powder to cocoa butter. Cocoa butter and cocoa powder are formed together after the formation of cocoa paste from cocoa beans.

It's obtained $\mathrm{R}^{2}$ as big as $93.91 \%$ from statistic test with linear system procedure on cocoa beans demand for cocoa paste industry. Its means that the exogenous variables in the model explain the variation of endogenous variable by $93.91 \%$ and the remainder $6.09 \%$ is influenced by other variables that are not included in the model. 
Cocoa beans demand for cocoa paste industry is cocoa beans demand to produce cocoa paste. It can be stated that cocoa beans demand for cocoa paste industry is simultaneously influenced by ratio of Indonesia cocoa paste price and world cocoa paste price, wages, cocoa beans demand to produce cocoa butter and cocoa powder. This is indicated by F-value as big as 69.41 with significance level less than $0.01 \%$.

Cocoa beans demand to produce cocoa paste is partially influenced by wages, cocoa beans demand to produce cocoa butter and cocoa powder. It can be seen that the wage coefficient is positive. It implies that the higher the wages of the workforce, the demand for cocoa beans to produce cocoa paste is increasing. It's because the wages of labor in Indonesia get attention from government and experience an increase that is adjusted to the minimum living necessity. This condition causes the industry to increase production volume to cover production costs, so the demand for cocoa beans to produce cocoa paste increases even though it happens increasing of wages.

The ratio of Indonesia cocoa paste price and world cocoa paste price has no significant effect on cocoa beans demand to produce cocoa paste. It's predicted by the value of the price ratio is relatively small. The price of cocoa paste Indonesia is cheaper than the world price. This condition is different from the results of research Ferryanta (2012) and Desweni et al (2015) which state that the output price of an industry affects the input demand.

Cocoa beans demand to produce cocoa paste is influenced by the demand for cocoa beans to produce cocoa butter with positive marked on its coefficient. The larger the cocoa butter is produced, the more cocoa paste is produced. This suggests that the increasing demand for cocoa beans to produce cocoa butter, it also increases the demand for cocoa beans to produce cocoa paste. In general, intermediate processed cocoa industry in Indonesia is a unified intermediate processed cocoa industry that produces cocoa paste, cocoa butter and cocoa powder. This is because the production process runs sequentially. If it is viewed from the export side, the market share of cocoa paste and cocoa butter are different countries. The main importing country of Indonesia cocoa butter is the United States, while the main importer country of Indonesia cocoa paste is Malaysia, so there is no competition both of them.

Cocoa beans demand to produce cocoa powder has a negative coefficient to the demand for cocoa beans to produce cocoa paste. This is predicted because cocoa paste and cocoa powder have the same main export destination country, that is Malaysia

Cocoa beans demand to produce cocoa powder has a negative coefficient on the cocoa beans demand to produce cocoa paste. Demand for cocoa beans to produce cocoa paste and powder eliminates each other. It is predicted that cocoa paste and cocoa powder have the same main export destination country, which is Malaysia.

Exogenous variables used in model of cocoa bean demand to produce cocoa powder are able to explain $94.17 \%$ variation of endogenous variable (cocoa beans demand for cocoa powder industry) and the rest of $5.83 \%$ influenced by other variables that are not contained in model.

Cocoa beans demand for cocoa powder industry is cocoa beans demand to produce cocoa powder. Cocoa beans demand for cocoa powder industry is simultaneously influenced by the ratio of Indonesia cocoa powder price and world cocoa powder price, wages; cocoa beans demand to produce cocoa butter and cocoa pasta. This is indicated by F-value as big as 72.65 with significance level less than $0.01 \%$.

Cocoa beans demand for cocoa powder industry is partially influenced by wages, cocoa beans demand for cocoa butter and cocoa pasta. Labor wages are always evaluated by government and have increased according to minimum living requirements. This condition causes the industry to increase the volume of production, so the necessity for cocoa beans is increasing even though it happens the wages increasing.

In contrast to the results of Ferryanta (2012) and Desweni et al (2015) studies which stated that the output price of an industry influences its input demand, the ratio of Indonesian cocoa powder price and world cocoa powder price does not significantly affect the cocoa beans demand for the cocoa powder industry. It is predicted because the value of price ratio is relatively small or the price of cocoa powder Indonesia is cheaper than world prices. 
Cocoa beans demand to produce cocoa butter affects the demand for cocoa beans to produce cocoa powder with a positive marked of coefficient. It indicates that the increasing demand for cocoa beans to produce cocoa butter, will also increase the demand for cocoa beans to produce cocoa powder. It's because they are the continued products of cocoa paste which is processed.

Cocoa beans demand to produce cocoa paste has a negative coefficient marked on the cocoa beans demand to produce cocoa powder. It indicates that the increasing demand for cocoa beans to produce cocoa paste, will decrease cocoa beans demand to produce cocoa powder. This is predicted that cocoa paste and cocoa powder have the same main export destination countries, namely Malaysia.

\section{CONCLUSION}

The necessity of cocoa beans required by the intermediate processed cocoa industry can be fulfilled from the production of cocoa beans domestically, and cocoa beans demand volume to produce cocoa paste, cocoa butter and cocoa powder show increasing after the restriction of cocoa beans export since 2010.

Cocoa beans demand to produce cocoa butter, cocoa beans demand to produce cocoa paste and cocoa beans demand to produce cocoa powder affect each other.

Cocoa beans demand to produce cocoa butter is affected by the world cocoa beans price, interest rate, cocoa beans demand to produce cocoa paste and cocoa beans demand to produce cocoa powder. Cocoa beans demand for cocoa paste industry is influenced by wages; cocoa beans demand to produce cocoa butter and cocoa powder. Cocoa beans demand for cocoa powder industry is influenced by wages, cocoa beans demand for cocoa butter and cocoa pasta.

\section{REFERENCES}

1. BTCOCOA, 2014. Industri Berebut Kakao, http://www.btcocoa.com.

2. Desweni Selly Prima, Sentosa Sri Ulfa, Idris, 2015. Analisis Permintaan dan Penawaran Jagung di Indonesia ( Studi Permintaan Jagung untuk Pangan dan Input Industri Peternakan Unggas, Jurnal Kajian Ekonomi, http://ejournal.unp.ac.id

3. Directorate General of Plantation, 2014. Statistik Perkebunan Indonesia, Kakao 20132015, ditjenbun.pertanian.go.id.

4. ICCO, 2014. Economics Committee, Fourth Meeting, Wembley- London.

5. Indonesia Central Bureau of Statistics (BPS), https://www.bps.go.id

6. FAO, Food and Agriculture Organization of the United Nations, www.fao.org.

7. Ferrianta Yudi, 2012. Dampak Liberalisasi Perdagangan ASEAN-China Free Trade Area (ACFTA) terhadap Kinerja Ekonomi Jagung di Indonesia, Universitas Brawijaya, Malang.

8. Coffee and Cocoa Research Center (Puslitkoka), Jember, Indonesia.

9. Suranovic M. Steven, 2003. International Trade Theory and Policy, http://internationalecon.com.

10. Trademap. Trade Statistics for International Business Development, http://www.trademap.org.

11. UN Comtrade. United Nations Comtrade Database - International Trade Statistics https://comtrade.un.org/ 